\title{
Mapping the "Mahkota Atap Masjid" or Decorative Roof Finial of Traditional Mosques in Malacca
}

\author{
Ros Mahwati Ahmad Zakaria, Nurfarahhanna Ismail, Zuliskandar Ramli, Muhammad Shafiq Mohd Ali \\ Institut Alam dan Tamadun Melayu (ATMA), \\ Universiti Kebangsaan Malaysia, Bandar Baru Bangi, 43600,Selangor, Malaysia
}

rosmahwati@ukm.edu.my; nurfarahhana9402@gmail.com; ziskandar@ukm.edu.my; muhdshafiq@ukm.edu.my

Tel: +603-8921-5822

\begin{abstract}
Decorative roof finials, also known as Mahkota Atap Masjid, are a unique identity and hallmark of Islam in Malacca. Today, there are more than 160 mosques throughout the state of Malacca, however, only 38 of them have a decorative roof finial. Therefore, the objectives of this research are: to map the location of these mosques and document their designs for heritage documentation. This research applies a qualitative methodology using air photography via drone (model DJI Phantom 3 Standard) for data documentation and typological analysis for establishing types of designs to study.
\end{abstract}

Keywords: Mosque; Islam; Malay; Architecture

eISSN: 2398-4287 @ 2019. The Authors. Published for AMER ABRA cE-Bs by e-International Publishing House, Ltd., UK. This is an open access article under the CC BYNC-ND license (http://creativecommons.org/licenses/by-nc-nd/4.0). Peer-review under responsibility of AMER (Association of Malaysian Environment-Behaviour Researchers), ABRA (Association of Behavioural Researchers on Asians) and cE-Bs (Centre for Environment-Behaviour Studies), Faculty of Architecture, Planning \& Surveying, Universiti Teknologi MARA, Malaysia.

DOI: https://doi.org/10.21834/e-bpj.v4i11.1760

\subsection{Introduction}

Mosques are considered landmarks of the local Muslim population throughout the world. In Islamic art history, they often bear symbols of the ruling power, typically integrated into the mosque's dome or minaret. Mosque architecture is distinctive to each Islamic kingdom or dynasty. In Malaysia, traditional mosque designs are integral to the identity of a particular area. Malacca, one of Malaysia's most historic states, is known for its traditional mosque architecture. Its most prominent and unique feature is the decorative roof finial. Mosques in other Malaysian states, namely Negeri Sembilan, Selangor, and Perak, also bear similar decorative roof finials during the 20th century. Over time, the demand for larger mosques increased to accommodate the growing Muslim population. Decorative roof finials were replaced by bulbous domes when spacious modern mosques superseded their traditional counterparts.

Malacca was a vital Islamic sultanate between the 14th and 16th centuries AD. It was also the busiest maritime entrepot in Southeast Asia. People of different nationalities, religions, and cultures came to Malacca to trade and lived alongside the local Muslims, the Malays. This melting pot existed prior, during and after Western colonization and Japanese occupation. Malacca's legacy today is built upon a multicultural understanding and heritage. One of its unique architectural heritage is the decorative roof finial, which adorns traditional mosques. Inspired by the Buddhist stupa, its design also pays homage to Islamic principles. Due to environmental and social factors these decorative roof finials are now endangered. Now only 38 mosques in Malacca still possess a decorative roof finial, out of more than 160 mosques.

The decorative roof finial or Mahkota Atap Masjid can only be seen in Malacca today. Most visitors to Malacca admire the beauty of traditional mosques at UNESCO World heritage sites like the Tengkera Mosque (17), Kampung Kling Mosque (17) and Kampung Hulu Mosque (1748). However, few people realize that the Mahkota Atap Masjid is at risk due to environmental and social factors. Only a few traditional mosques in Malacca still possess the Mahkota Atap Masjid. Some mosques have even removed this

eISSN: 2398-4287 @ 2019. The Authors. Published for AMER ABRA cE-Bs by e-International Publishing House, Ltd., UK. This is an open access article under the CC BYNC-ND license (http://creativecommons.org/licenses/by-nc-nd/4.0). Peer-review under responsibility of AMER (Association of Malaysian Environment-Behaviour Researchers), ABRA (Association of Behavioural Researchers on Asians) and CE-Bs (Centre for Environment-Behaviour Studies), Faculty of Architecture, Planning \& Surveying, Universiti Teknologi MARA, Malaysia.

DOI: https://doi.org/10.21834/e-bpj.v4i11.1760 
architectural feature and substituted them with popular Islamic symbols. The most common are domes topped with a crescent moon and five-pointed star. This study is significant, as it locates and maps the positions of traditional mosques in Malacca that still have a Mahkota Atap Masjid. It also documents the designs to develop documentation and a local heritage inventory. While documenting locations, this study also looked into design variations that are common to the three main districts in Malacca - Jasin, Melaka Tengah dan Alor Gajah.

The objectives of this study are first to map the location of mosques in Malacca with decorative roof finials known as Mahkota Atap Masjid. Second, it is to document and categorize them according to typology for future research reference. The unpopular use of decorative roof finials in new mosque projects also contributes to this study. These objectives are important to this fundamental study due to the lack of inventory and data related to this endangered heritage.

\subsection{Literature Review}

The mosque is an important landmark and identity for Muslims in a particular area. Its design and structure are often influenced by local tastes, traditional materials, and existing building cultures (Özçakı, M. 2018). Most traditional mosques are infused with a local identity, a practice that is now being revived in new mosques, without Arabic-styled domes (Jamaludin \& Salura 2018). Decorative roof finials are considered crucial architectural elements in both religious and residential structures of the Malay world. Both locals and researchers refer to decorative roof finials by different names. On the East Coast, they are called Tunjuk Langit, which can be translated to "a sign that shows the sky." They are carved from a piece of wood into a cylindrical shape with a pointed tip, like an arrow. A decorative roof finial can be placed in different locations, like above the main door or on top of the main house. There is usually just a single decorative roof finial adorning a mosque.

Another common Malaysian name for the decorative roof finial is the Buah Buton (Abdul Halim, 2004). Most often seen in Kelantan and Terengganu, where it is also known as Buah Gutung, it is often described as having a round, multi-tiered shape that is akin to a water vessel. It can be seen adorning traditional roofs called bumbung limas, also known as perabung lima or pyramid roof (Utaberta et. al. 2012; Siti Dalila and N. Utaberta, 2013).

The decorative roof finial is known as Mahkota Atap Masjid in this research. This is due to its position at the pinnacle of the roof and its multi-tiered, crown-shaped design. The decorative roof finial is closely associated with Malay architecture. On the East Coast, it is better known as Tunjuk Langit or Buah Buton (Abdul Halim,2004). But due to the reasons above, in Malacca, it is called Mahkota Atap Masjid. Other than the use of different names, the employment of different materials and designs are also applied. In Malacca, the Mahkota Atap Masjid is made of mixed concrete (Ros Mahwati, 2018), while on the East Coast, the Buah Buton is made of wood.

In Malacca, the Mahkota Atap Masjid is available in various designs and multiple tiers. In general, the shape of the Mahkota Atap Masjid is a stupa, which is a Buddhist symbol that pullulates throughout South, Southeast Asia, and East Asia. Some researchers consider the stupa a cultural artifact that is closely related to the Indian context (Snodgrass, 1985). This correlates with the fact that much of Southeast Asia was once Hindu-Buddhist. Therefore, many of the arts and cultures of this region bear Hindu-Buddhist aesthetics. They are still being applied today, hundreds of years after the arrival of Islam. However, adjustments were made to adhere to Islamic teachings. An extant cultural symbol is the decorative roof finial known as Mahkota Atap Masjid.

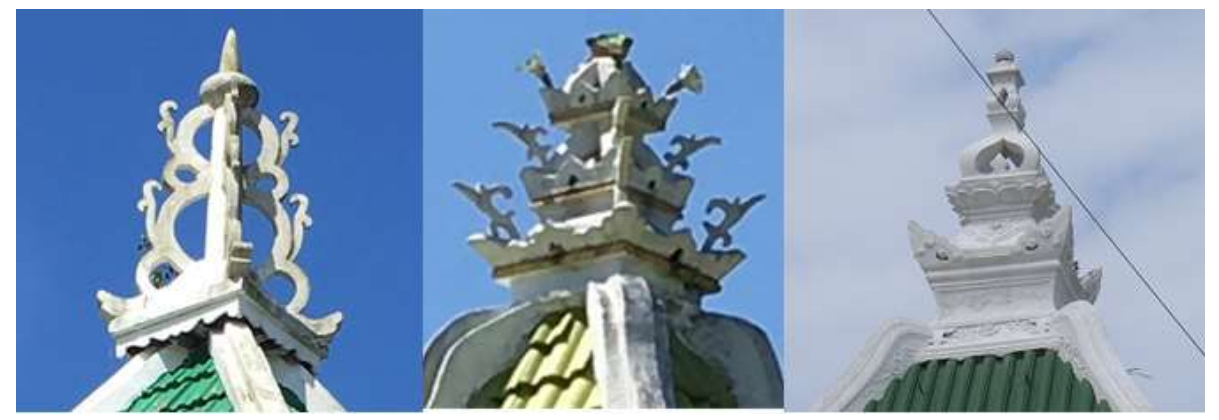

Figure 1: Different types of decorative roof finials, or Mahkota Atap Masjid, decorating mosques in Malacca.

The shape of the Mahkota Atap Masjid and its relation to the Hindu-Budhha context has led to prevailing misconceptions. Therefore, this architectural element has become endangered. Members of the local communities have taken action by removing and replacing them with a symbol deemed more synonymous with Islam, namely the dome (Ros Mahwati, 2017). Additionally, environmental factors like the climate and weather have also contributed to the deterioration and diminishing quantity of this decorative element.

\subsection{Methodology}

This research applies a qualitative research method, including aerial photography. To document decorative roof finial designs up close a DJI Phantom 3 Standard drone was used with permission from the Civil Aviation Authority of Malaysia CAAM). The Global Positioning System (GPS) and Google maps were other research methods used to map the locations and coordinates of mosques 
with decorative roof finials. All documentation activities were conducted with the approval and knowledge of related Malaccan authorities. This includes the Civil Aviation Authority of Malaysia (CAAM), Chief Minister's Office, Jabatan Agama Islam Melaka (JAIM), mosque administration offices and the state police department.

With help from Jabatan Agama Islam Melaka (JAIM), a survey was conducted to confirm mosque locations before aerial photography could begin. Upon confirmation, researchers briefed CAAM about the project and aerial photography timeline. To obtain clearance, the study area had to exclude military camps, airports, and aviation training centers.

Using GPS to ensure accuracy, the location of each mosque was locked. Aerial photography is essential as it can capture decorative roof finials from a $360^{\circ}$ angle. Once photographic data was collected, the roof finial designs were studied using a typological analysis. Data mapping and analysis were divided according to Malacca's three districts - Jasin, Melaka Tengah, and Alor Gajah, which also represent the limitations of this study.

\subsection{Data Analysis}

One of the few Malaysian states that still possesses distinctive and traditional mosque architecture is Malacca. Many mosques have been built in Malacca to serve communities as religious centers in recent decades. From the 169 mosques in Malacca today, only 35 of them have a Mahkota Atap Masjid. Six of them are located in the district of Jasin (Map 1), 16 in the district of Melaka Tengah (Map 2) and 13 in Alor Gajah (Map 3).

Jasin is located next to the state of Johor Darul Takzim. A rural district, its administrative center is based in a small town. The main economic activities are rubber tapping (Hevea brasiliensis) and palm oil cultivation (Elaeis guineensis). Manufacturing, business, and government sectors are conducted on a much smaller scale.

Jasin's 6 traditional mosques are quite distant from one another. The most remote among them is Masjid Kampung Rim (Label no. 1). Mosques labeled with numbers 1, 2, 3 and 4 (please refer to Map 1 and Table 1) are in inland areas. Meanwhile, mosques labeled with numbers 4 and 5 (please refer to Map 1 and Table 1) are near the coastline. This study also found that all the mosques are near the main road.

The elderly occupy most homes near the mosques, and no new residential areas have been developed nearby. This indicates that most of the people who use these mosques are locals who have lived there for many years.

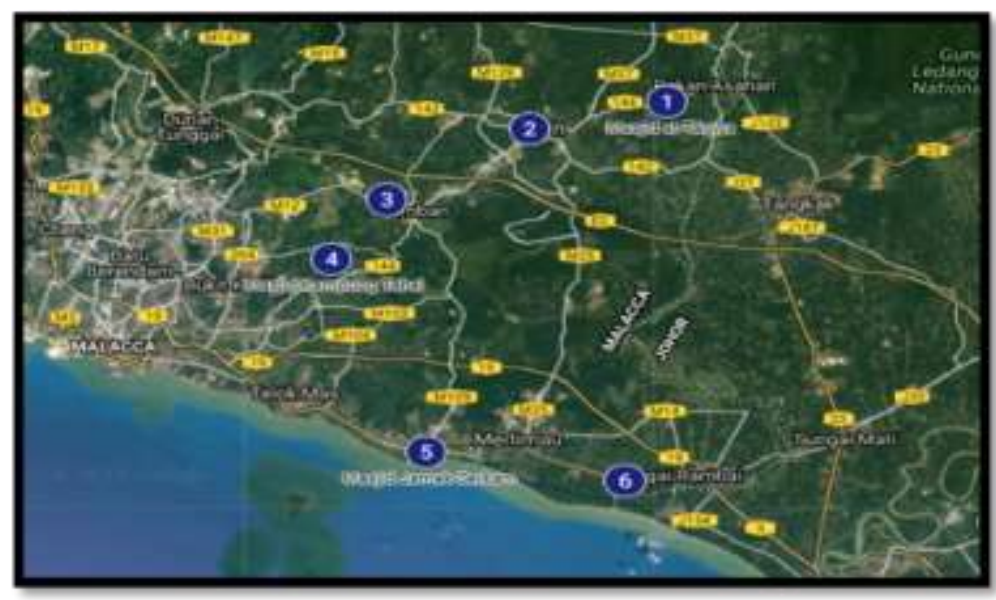

Map 1: Location of traditional mosques in the Jasin district with a Mahkota Atap Masjid.

Table 1: List of traditional mosques in the Jasin District with a Mahkota Atap Masjid.

\begin{tabular}{|l|l|l|}
\hline No. & Mosque's Name & GPS Coordinates \\
\hline 1. & At-Taqwa Mosque, Kg. Rim & $2.32475,102.48567$ \\
\hline 2. & Old Mosque of Ayer Barok & $2.31032,102.42789$ \\
\hline 3. & Nurul Iman Mosque, Ayer Panas & $2.27305,102.36631$ \\
\hline 4. & Kampung Tehel Mosque & $2.2414,102.34243$ \\
\hline 5. & Jamek Mosque Serkam & $2.13863,102.38267$ \\
\hline 6. & Sebatu Mosque & $2.12342,102.46819$ \\
\hline
\end{tabular}

Melaka Tengah, which is Malacca's economic and administrative center, is much busier in comparison to the other two districts studied. Melaka Tengah is found to have the highest number of traditional mosques with a Mahkota Atap Masjid. Most of them are located near the coastline, and are labeled as numbers 7, 8, 14, 16 and 15 (please refer to Map 2 and Table 2). Mosques located inland belong to urban and rural areas. Urban mosques include top tourist attractions like the Tengkera Mosque (no. 13), the Dutyung Mosque (no. 6), the Hang Tuah Village Mosque and the Bandar Hilir or Jonker Street mosque (numbers 3 and 4 . Please refer to Map 2 and Table 2). Other mosques studies are located in prime areas (numbers 1 and 2), which are in the business enclave. Finally, there are both traditional and modern mosques located in villages and residential areas (please refer to Map 2 and Table 2). 
The Melaka Tengah district provides an interesting landscape for mosques, as most are nestled in predominantly non-Muslim neighborhoods. For example, the Fathur Rahman Mosque, Pengkalan Rama (labeled as no.1), Kampung Kling Mosque (labeled as no.3), Bukit China Mosque (labelled as no. 2), Tengkera Mosque (labelled as no. 5) and Kampung Hulu Mosque (labeled as no. 4) are located in areas with a predominant Chinese population and alongside their business activities. There are also mosques built alongside traditional Malay communities, such as the Al-Faizin Mosque, Kampung Bertam Malim (labeled as no. 11), Wadhi As-Sidiq Mosque, Paya Rumput Jaya (labeled as no. 10), Al Falahin Mosque, Alai Melaka (labeled as no. 16), Al Khairiah Mosque, Telok Mas (labeled as no. 14) and Jamek Mosque, Kampung Duyong (labeled as no 13).

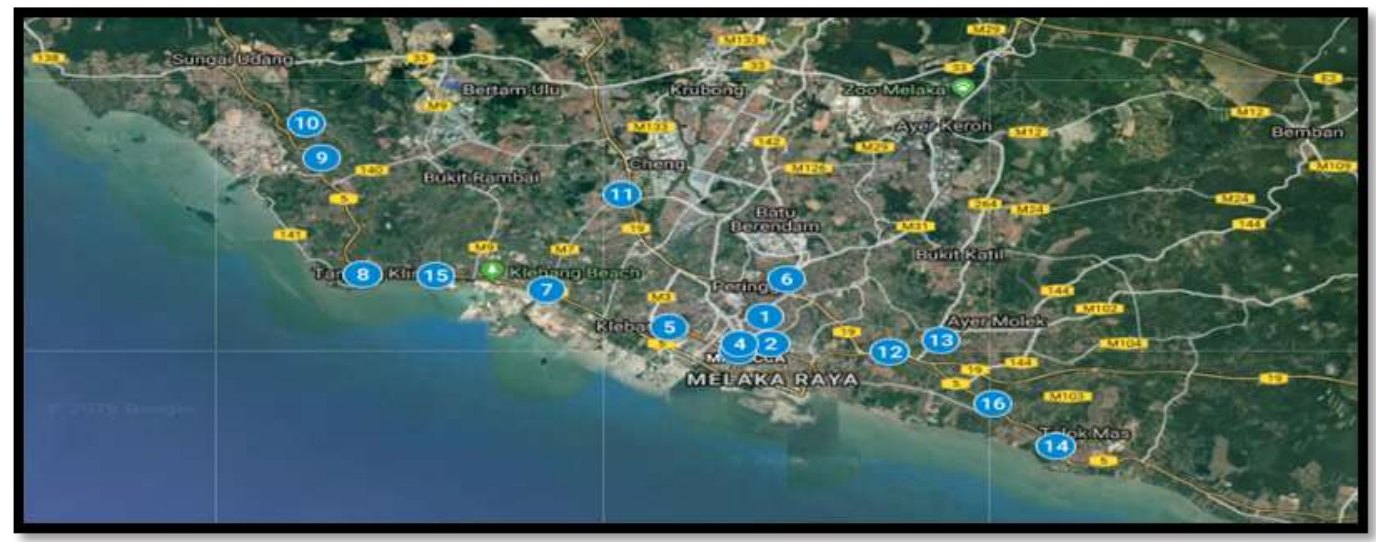

Map 2: The location of traditional mosques in the Melaka Tengah District with a Mahkota Atap Masjid.

Table 2: A list of traditional mosques in the Melaka Tengah District with a Mahkota Atap Masjid..

\begin{tabular}{|c|l|l|}
\hline No. & \multicolumn{1}{|c|}{ Mosque's name } & \multicolumn{1}{|c|}{ GPS Coordinates } \\
\hline 1. & Fathur Rahman Mosque, Pengkalan Rama & $2.20774,102.2536$ \\
\hline 2. & Bukit Cina Mosque & $2.19927,102.25494$ \\
\hline 3. & Kampung Kling Mosque & $2.19679,102.2475$ \\
\hline 4. & Kampung Hulu Mosque & $2.19924,102.24762$ \\
\hline 5. & Tengkera Mosque & $2.20418,102.23201$ \\
\hline 6. & An-Nur Mosque Peringgit & $2.22019,102.25876$ \\
\hline 7. & Saad Ibni Abi Waqqas Mosque,Jalan Klebang Besar & $2.21654,102.20406$ \\
\hline 8. & Bilal Bin Rabah Mosque,Tanjung Kling Melaka & $2.22147,102.16225$ \\
\hline 9. & Tangga Batu Kecik Mosque & $2.25916,102.15286$ \\
\hline 10. & Wadhi As-Siddiq Mosque, Paya Rumput Jaya & $2.27033,102.14961$ \\
\hline 11. & Al-Faizin Mosque, Kampung Bertam Malim & $2.24746,102.22134$ \\
\hline 12. & Al-Abrar Mosque Semabok & $2.19636,102.28186$ \\
\hline 13. & Jamek Mosque, Kampung Duyong & $2.20007,102.29382$ \\
\hline 14. & Al Khairiah Mosque, Telok Mas & $2.16593,102.3199$ \\
\hline 15. & Pokok Asam Mosque & $2.221,102.17884$ \\
\hline 16. & Al Falahin Mosque, Alai Melaka & $2.17945,102.30533$ \\
\hline & & \\
\hline
\end{tabular}

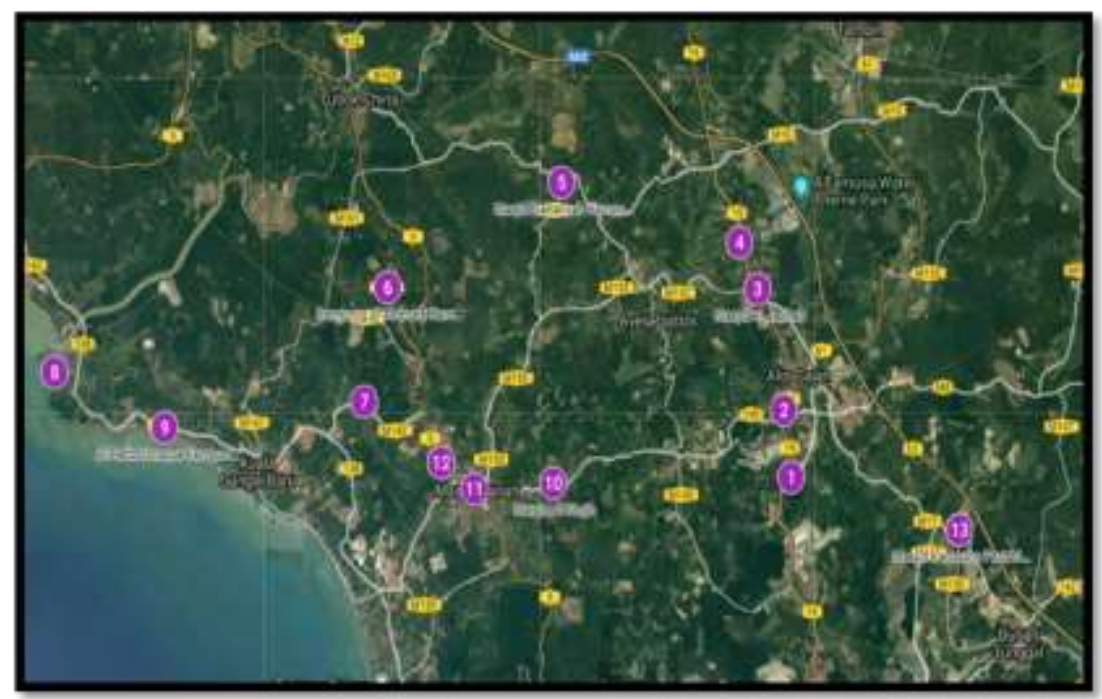

Map 3: The location of traditional mosques in the Alor Gajah District with the Mahkota Atap Masjid. 
Mapping conducted in this district shows that most mosques are not ideally located to serve the local community. Instead of being located in business centers, as mentioned above, some mosques in Melaka Tengah are located at busy main roads, such as the Tangga Batu Kecik Mosque (labeled as no 9), the Tengkera Mosque and the Saad Ibni Abi Waqqas Mosque at Jalan Klebang Besar (labeled as no. 7). These locations have very limited reserved areas for the mosques. On the other hand, some of the newer mosques have been purposely built away from residential areas. This is largely due to land development and the migration of older generations. The Pokok Asam Mosque (labeled as no. 15), for example, is located in an area with few houses.

Alor Gajah is the third Malaccan district studied. Located next to the neighboring state of Negeri Sembilan, it is still underdeveloped, although a few industrial areas have been in operation for a few years. This study found that Alor Gajah has 13 traditional mosques with a Mahkota Atap Masjid. They are located in remote areas and far apart. The Belimbing Dalam Mosque, a traditional mosque in this district, was in ruins when the research team arrived at the location. The mosque had been abandoned for some time before it suffered damaged dan finally disintegrated due to neglect by the villagers once a new mosque had been built. The mapping of mosques in Alor Gajah area could be seen in Map 3.

Table 3: A list of traditional mosques in the Alor Gajah District with the Mahkota Atap Masjid.

\begin{tabular}{|l|l|l|}
\hline No. & Mosque's name & GPS Coordinates \\
\hline 1. & Sungai Petai Mosque & $2.35563,102.20927$ \\
\hline 2. & Al Aman Mosque & $2.37313,102.207$ \\
\hline 3. & Al Jauhari Mosque & $2.40494,102.19868$ \\
\hline 4. & Kg Melekek Luar Mosque & $2.4168,102.19264$ \\
\hline 5. & Dahariyah Mosque & $2.43272,102.13607$ \\
\hline 6. & Al-Muhtadi Mosque & $2.40525,102.08059$ \\
\hline 7. & Ar-Razak Mosque & $2.37537,102.0729$ \\
\hline 8. & Al-Bar Mosque & $2.38311,101.97428$ \\
\hline 9. & Al-Hafiz Mosque & $2.36848,102.00944$ \\
\hline 10. & Al Mujib Mosque & $2.35426,102.13322$ \\
\hline 11. & Old Mosque of Masjid Tanah & $2.35234,102.10815$ \\
\hline 12. & Datuk Janggut Mosque & $2.35916,102.09763$ \\
\hline 13. & Kampung Parit Melana Mosque & $2.34199,102.26311$ \\
\hline
\end{tabular}

\subsection{Discussion}

This study seeks to establish an architectural heritage inventory that documents the surviving Mahkota Atap Masjid in Malacca, particularly their existing numbers and designs. No one is certain if this heritage will survive into the next generation. The mapping conducted in this study provides vital information on the anatomy and general design of the Mahkota Atap Masjid. General observations reveal that the Mahkota Atap Masjid comprises of several sections, categorized as the top knot, head, body, and base (as seen in Illustration 1). These four sections were visible in each Mahkota Atap Masjid studied. The analysis also showed that there are four Mahkota Atap Masjid designs. The first typology is the solid design (Figure 2), where the Mahkota Atap Masjid is made of concrete, is three dimensional and has four-paneled faces. This design does not have an integrated cutout frame. The second typology is the semi-solid design (Figure 3), which incorporates both the solid and cutout style in one. The third is the cutout concrete frame design (Figure 4), in which nearly 90 percent of the form is made of concrete frame cutouts. The final typology is the iron frame design (Figure 5), made from iron bars and bent to form a design.

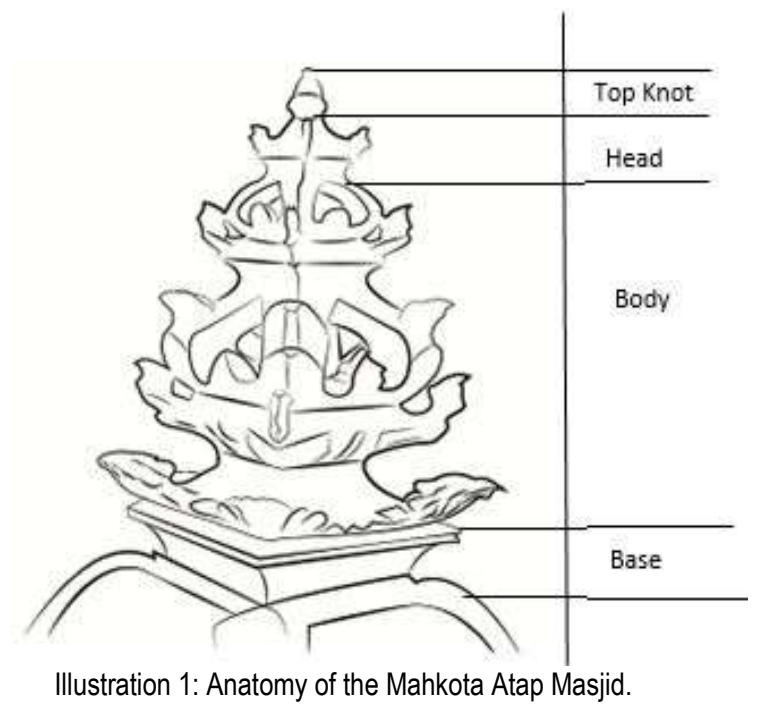




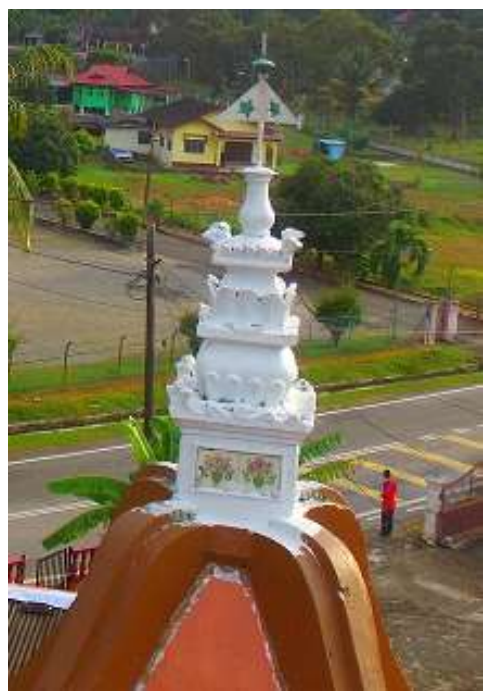

Fig. 2: Mahkota Atap Masjid with a solid design.

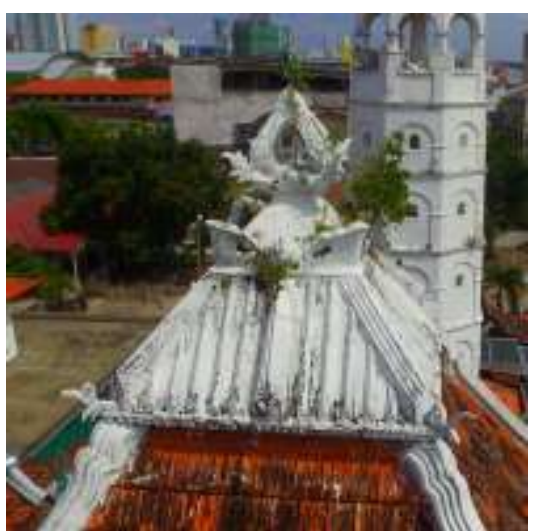

Fig. 3: Mahkota Atap Masjid with a semi-solid design.

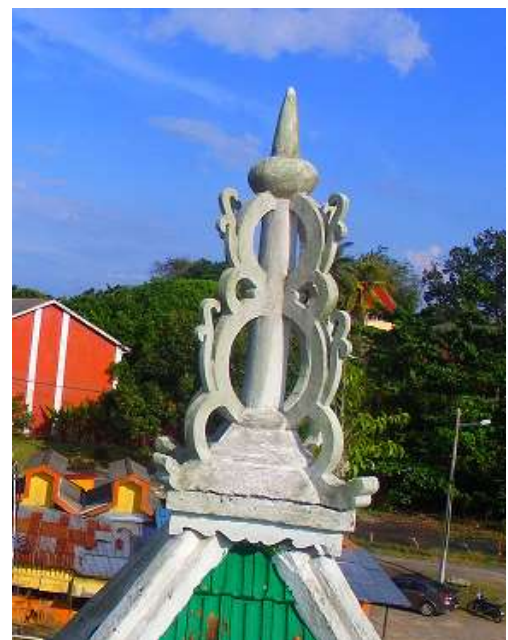

Fig. 4: Mahkota Atap Masjid with a concrete frame design. 


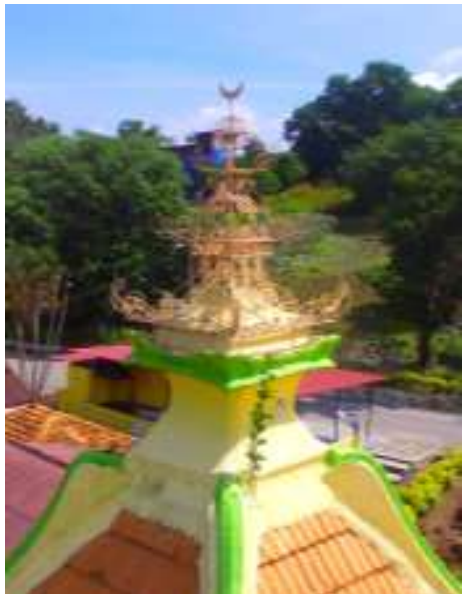

Fig. 5: Mahkota Atap Masjid with an iron frame design.

The third group comprises of the concrete frame design, which is the most popular and is used widely in all three Malaccan districts. Though the type bears a similarity, the appearance varies. The fourth group yields just one example, found at the Jamek Mosque in Duyong (Figure 5). This area is famously related to the Malay legend of Hang Tuah. Its Mahkota Atap Masjid is made of thin metal bars that are bent to form an intricate finial. It is similar to a mosque structure with a dome design, topped by a crescent.

Not many Mahkota Atap Masjids feature additional decorative elements such as tiles, calligraphy or glass flowers. Only three mosques had tile decorations, the Tangga Batu Kecik Mosque $(2.25916,102.15286)$ and the Wadhi As-Siddiq Mosque (2.27033, 102.14961) in Melaka Tengah; as well as the al-Mujib Mosque $(2.35426,102.13322)$ in Alor Gajah. As for calligraphic decoration, the Pengkalan Rama Mosque $(2.20774,102.2536)$ bore the best example. The calligraphic style used is identified as Sino Arabic, often used for Qur'anic inscriptions and Chinese Muslim calligraphic paintings in China. The phrases employed are the Shahadah (Islamic declaration of faith) and the names of the Prophet's four companions - Abu Bakar, Umar, Uthman, and Ali.

Observations show that many locals were concerned over the state of old mosque buildings. However, few paid close attention to their architectural elements. It is certain, however, that Mahkota Atap Masjid designs vary according to different areas. They were created to complement the Limas roof of traditional mosque architecture and would logically be made at the same time the building was completed. It is also believed that buildings with a Mahkota Atap Masjid were of higher status than the buildings around it. Often, the mosque is the only building in an area with a Mahkota Atap Masjid, befitting its exalted position as a sacred building and place of worship for Muslims.

The designs in all the typologies stated above are in line with Islamic teachings, whereby no living figures like humans or animals are depicted. There is a hint of figurative design in the shape of a bird's or dragon's head, stylized in a foliate design as an additional decoration for each angle at each level of the roof finial. The stylization of animal motifs into a foliate design is one of the methods used by Malay Muslim artists to enrich their Islamic art heritage.

The mapping of this endangered Islamic heritage also shows that more than 90 percent of the names of these traditional mosques were changed to Arabic-sounding ones. These mosques were previously named after the local area, such as the Tengkera Mosque. In the Jasin area, 3 out of 6 of the traditional mosques with Mahkota Atap Masjid have adopted Arabic names.

The Arabic names chosen could be divided into three main groups. Firstly the Names of Allah, or the Asmaul-Husna. One such example is Ar-Razak, which means The Provider. Secondly is the names renowned figures in Islamic history, such as Saad Ibn Abi Waqqas. Thirdly are Arabic words with benevolent meanings, such as Nurul Iman, which means the light of faith. Unfortunately, the spelling of these Arabic names often differs from the standard Arabic transliteration system.

\subsection{Conclusion and Recommendation}

In conclusion, this study has yielded both explicit and implicit results. The mapping of Malacca's endangered Islamic art heritage, known as the Mahkota Atap Masjid, is essential to the creation of an inventory of local heritage, in Malacca specifically, and Malaysia generally.

If proactive actions aren't taken to protect it and the younger generation isn't taught about its significance, this heritage will eventually disappear, undocumented. The locations of these mosques and the designs of these Mahkota Atap Masjids are vital for local history. In comparison to other Malaysian states, Malacca has the widest variety of Mahkota Atap Masjid designs. As a decorative element, this heritage strongly identifies the artistic traditions of Islam in this area. The implicit results show that the local Muslim population had been trying to manifest Islam as much as they can by directly copying architectural designs from other Islamic regions, especially the Middle East. They have even adopted Arabic names for their mosques, which are deemed to sound holier and more Islamic. A study should be conducted to learn if the local Muslims understand the meaning of the Arabic terms chosen for their mosque. This study is one of the many efforts underway to highlight the forgotten elements of our local Islamic heritage. If no one 
takes action, this heritage will disintegrate, as the Belimbing Dalam Mosque did. No one took note of the mosque's Mahkota Atap Masjid, its name or even its existence.

\section{Acknowledgements}

This study is prepared under the Research University Grant (GUP 2018-02) budget and thank you to the Universiti Kebangsaan Malaysia for the grant awarded.

\section{References}

Abdul Halim Nasir. (2004). Mosque Architecture in the Malay World. Bangi: Universiti Kebangsaan Malaysia.

Jamaludin. J, P. Salura. (2018). Understanding the Meaning of Triangular Shape in Mosque Architecture in Indonesia. International Journal of Engineering \& Technology. 7 (4.7). 458-462.

N. Utaberta, S. D. M. Sojak, M. Surat, A. I. Che-Ani and M.M. Tahir (2012). Typological Study of Traditional Mosque Ornamentation in Malaysia - Prospect of Traditional Ornament in Urban Mosque. World Academy of Science, Engineering and Technology International Journal of Civil, Environmental, Structural, Construction and Architectural Engineering Vol: 6, No:7, 2012. 457- 464.

Nursuriani Shaffee. Ismail Said. (2013). Types of Floral Motifs and Patterns of Malay Woodcarving in Kelantan and Terengganu. Procedia - Social and Behavioral Sciences, 105 ( 2013 ) 466 - 475. Retrieved from https://people.utm.my/ismail/files/2015/01/Types-of-Floral-Motifs-and-Patterns-of-Malay-Woodcarving-in.pdf.

Özçakı, M. (2018). Interpreting the Mosque Architecture. ulakbilge, 6(23), 459-483. Retrieved from http://www.ulakbilge.com/makale/pdf/1523218293.pdf.

Siti Dalila Binti Mohd Sojak. Nangkula Utaberta. (2013). Typological Study of Traditional Mosque Ornamentation in Malaysia-Comparison Between Traditional and Modern Mosque. Proceedings International Conference On Architecture And Shared Built Heritage Conference. 101-118. Retrieved from https://www.academia.edu/4632605/Typological_Study_of_Traditional_Mosque_Ornamentation_in_Malaysia-Comparison_between_Traditional_and_Modern_Mosque

Ros Mahwati Ahmad Zakaria, Siti Nor Azhani Mohd Tohar \& Rabiah Abdul Rahman. (2018). Warisan Ketara Seni Islam Tempatan: Mahkota Atap Masjid Tradisional Melaka. Asian Journal of Environment, History and Heritage. Vol. 2. Issue 1, 185-196.

Snodgrass. Andrian. 1985. The Symbolism of the Stupa. New York: South East Asia Program (SEAP).1-36. 